\title{
P02.168. Safety issues and orthorexia in paediatrics
}

\author{
I von Rosenstiel", J Stam, W Schats \\ From International Research Congress on Integrative Medicine and Health 2012 \\ Portland, Oregon, USA. 15-18 May 2012
}

\section{Purpose}

As an antithesis to the paediatric obesity pandemic, the eating disorder of orthorexia in parents and children is an emerging condition. Well-intentioned parents strictly limit their childrens' food groups, be it carbohydrates, transfats, animal products, dyes or sugars, leading to dangerous extremes and malnutrition.

\section{Methods}

We descibe our clinical experiences with families with extreme diets at our outpatient integrative medicine clinic in Amsterdam, the Netherlands. Data were analysed on parent and child demographics and clinical characteristics, family health concerns, educational level, lifestyle and social consequences.

\section{Results}

During 12 months, a total of 4 cases of extreme diets were reported from a cohort of 41 patients. Two cases concerned sugar-free diets, one case of a vegan diet and one case of $100 \%$ raw food. Negative medical outcomes were nutritional deficiencies, stunting, concentration and developmental disorders, and social isolation. The raw food case involving a mother with orthorexia and her 14 year old son has led to a court case, causing a national debate on autonomy of the family versus child abuse.

\section{Conclusion}

Pediatricians should be more knowledgable about the phenomenon of orthorexia and the potential warning signs. The so-called "worry factor" and "feelings towards food groups" are the biggest indicators to aid in preventive efforts. More studies in the pediatric field adressing effectiveness and safety issues of specific diets are

Slotervaart Hospital, Amsterdam, Netherlands needed to assist the experts in daily practice and medical court cases.

Published: 12 June 2012

doi:10.1186/1472-6882-12-S1-P224

Cite this article as: von Rosenstiel et al.: P02.168. Safety issues and orthorexia in paediatrics. BMC Complementary and Alternative Medicine 2012 12(Suppl 1):P224.
Submit your next manuscript to BioMed Central and take full advantage of:

- Convenient online submission

- Thorough peer review

- No space constraints or color figure charges

- Immediate publication on acceptance

- Inclusion in PubMed, CAS, Scopus and Google Scholar

- Research which is freely available for redistribution

\section{() Biomed Central}

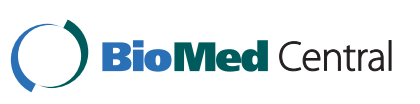

(c)

(2012 von Rosenstiel et al; licensee BioMed Central Ltd. This is an Open Access article distributed under the terms of the Creativ reproduction in any medium, provided the original work is properly cited. 